\title{
Deconstruction of Gambus Art Instrumentation, as a Prototype of the Emergence of Bandar Art in Pariaman West Sumatera
}

\author{
Martarosa* \\ Music Departement, Faculty Of Performing Arts, Institut Seni Indonesia Padangpanjang \\ Rozalvino \\ Music Departement, Faculty Of Performing Arts, Institut Seni Indonesia Padangpanjang \\ Imran Abdoel Gani \\ Music Departement, Faculty Of Performing Arts, Institut Seni Indonesia Padangpanjang
}

\begin{abstract}
The establishment of gambus art in Pariaman as a port city is inseparable from the influence of Gujarat Arabs and western colonialism. In the past, Pariaman was famous as a place where Islam first entered the coastal regions of West Sumatra. This region was dominated by the interests of the sovereigns socially, politically, economically and culturally by migrant traders and Western colonials for quite a long time. This research, musicology, aims to see the deconstruction of a gambus orchestra instrument as a prototype of the emergence of Bandar art in the city of Pariaman namely gamat music and katumbak music. The research method used is descriptive analysis and interpretive methods using qualitative data in two aspects textual and contextual. It is suspected that, in terms of the development of the Gambus orchestra instrumentation in the city of Pariaman in 1965, it was marked not only by using acoustic musical instruments such as, gambus imported from Arabic but also by using other acoustic musical instruments imported from the West such as: violins, guitars, accordion, harmonium, cello pick, tipa drum, castanyet, and bass contra. Furthermore, this type of instrumentation is also used by other similar music groups, in the coastal regions of West Sumatra
\end{abstract}

Keywords: Deconstruction, Instrumentation, Gambus, Art, Bandar.

DOI: $10.7176 / \mathrm{ADS} / 79-05$

Publication date: December $31^{\text {st }} 2019$

\section{A. Introduction}

The popularity of gambus music in the city of Pariaman in the 1965 was considered as one of the prototypes in line with the emergence of a kind of Bandar art which had also been directed in the region such as gamat music and katumbak music. Although gambus music as previously predicted is a form of presentation of Islamic religious music, besides being used for entertainment it also functions as a medium of spiritual education delivered by the singer to the audience through text or poetry. However, the development of Gambus musical instruments in Pariaman in 1965 can also be marked in addition to using acoustic musical instruments such as, gambus imported from Arabic and also equipped using other acoustic musical instruments imported from the West such as: violin, guitar, accordion, harmonium, cello strings, tipa drum, castanyet, and contra bass pick..

Lono Simatupang explains that, the growth and development of arts and cultures from various regions in Nusantara is an identity that can describe a wall, where the two ends meet, even though there is a separation between inner space viewed from outside space (2013: 239). This sight can be used as a concept to see a general description of some of the issues to be raised. It is assumed that there are similarities and differences of cultural phenomena that occur in the development of instrumentation of gambus orchestra as Islamic religious musical content with musical aspects of other performing arts groups such as, gamat music and katumbak music which have long been growing and developing as art-culture community in the city of Pariaman. Musically, this aspect of instrumentation is most likely to come from Western music idioms through Dutch colonialism and was also influenced by Arabic music through Gujarat merchants and the spread of Islam to the West Coast of Sumatra, especially in the West Sumatra Coastal region where Pariaman was once known as the City of the Port of Harbor in the western region of Sumatra, namely in the region of Pariaman and Tiku. In musicology review as a musical study, this process is a very interesting and important phenomenon to be studied. Therefore this case is the focus of this research..

Further related to deconstruction is the theory of philosophical and literary trends that have recently been applied to music. This concept was most clearly identified with the French theorist Jacques Derrida through classical texts in the 1960s, Derida's works influenced much the development of post-structuralist thought thereafter, such as his writings entitled Of Grammatology (Derrida 1976: 45). Derrida in principle always opposes the meaning of texts that are understood in terms of definition alone, Derrida encourages to read texts critically and question the status of language that bears to the text itself.

Derrida insisted that deconstruction is not a methodology or a system, but can be understood as a way to read 
and interpret subversive texts. Deconstruction involves a 'always-present' process in the text, and deconstructive reading is what involves the identification and explanation of this presence as counter-logic to what initially appears to be the most logical and natural interpretation (Kennenth Gloaga and David Beard, 2005: 38).

The concept of deconstruction offered by Derrida mainly talks about dismantling the meaning of texts that have been established or in a structuralist view, "the position of the text is final based on the understanding and interpretation of people in the past, both interpretations of the text and reality". The structuralist group's understanding of the text is denied by Derrrida with his concept of deconstruction. Derrida presents suspicion towards the text and the meaning of the text understood by the adherents of the structuralism. In the past, the Text was produced in accordance with the reality that developed at that time. In the sense that understanding the text of the past needs to be inculcated suspicions, to bring up the understanding and interpretation in accordance with the present context without any intervention on the text.

It is important to instill freedom for individuals in interpreting texts and social realities that flow without elements of domination and interests. This is what causes objectivity to science itself. Derrida's deconstruction was used as the analysis knife in this study. Derrida's deconstruction concept always instills suspicion of the text and reality that has occurred so far. The concept of deconstruction must be understood and interpreted openly and not rigidly. In interpreting texts and social reality, it must be done by presenting reality into the present context. The reality of the past can not only be understood as a reality that must be taken for granted, it must be raised suspicion of the text and reality of the past to get the truth of objective science.

The emergence of texts, art and tradition in principle cannot be separated from the influence of power, politics, economics and culture in which reality is produced. Reality cannot be present by itself, neither can gamat music, and katumbak as bandar art. The presence of gamat music, and katumbak as a port of art are much influenced by the social reality that was present at that time.

The development of gambus music as the art and culture of the people in Pariaman, West Sumatra, is musically seen to influence the emergence of other music groups in Pariaman such as gamat and katumbak music. Even though gamat and katumbak music in Pariaman at this time are experiencing a setback than before, it does not mean extinct, at certain events both types of music are still seen actively performing as a cultural art in Pariaman. Another development is the allegation of similarities and differences in cultural phenomena that occur in the development of instrumentation of gambus orchestra as Islamic religious musical content with musical aspects of other music performing arts such as gamat and katumbak. These musical aspects is most likely to be sourced from Western musical idioms through Dutch colonialism and also previously influenced by by Middle Eastern music through Gujarat merchants and the spread of Islam to the West Coast of Sumatra especially in the West Suamatera Coastal region, Pariaman as the Bandar City (Port City).

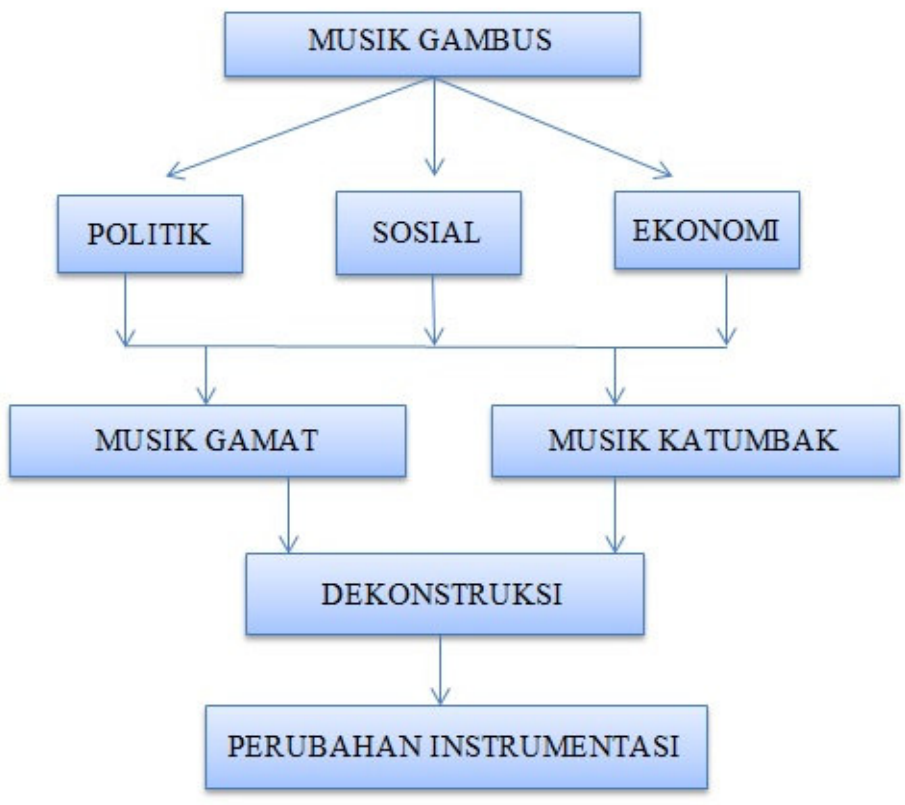

Chart 1. Deconstruction of the Process of Forming Art Bandar (Compiled by: Martarosa) 


\section{B. DISCUSSION}

\section{Cultural, Economic and Political Colonialism}

A brief history of the City of Bandar in Pariaman is inseparable talking about the City of Bandar in the Minangkabau Coast of West Sumatra, which in this case talks about activities in the form of trade networks in Nusantara and on the west coast of Sumatra's coast. Trade network in question is a social process that occurs when the exchange process of various trade actors including indigenous people or merchants, with foreign or foreign traders (Gusti Asnan, 2007: 147).

The period of 1400-1650 was the era dominated by trade networks and was always a vital thing for Southeast Asia. This trading network also took place in cities in various Nusantara regions, and had very close contacts with other port cities on the coast, such as Hindustan, Outer India, China and Japan (W.F. Wertheim, 1999: 2). Uniquely during this trade period, it could be reached by sea traffic and maritime control between China (the largest international market in recorded history) and residential centers such as India, the Middle East and Europe (Anthony Reid, 201: 3).

Likewise, the cities in the west coast of Sumatra Coast during the conquest of Aceh. This region with Europe (the Netherlands) had begun to establish trade relations since the end of the 16th century. Even though DutchAceh relations in the 17th century and the following century gave rise to political tensions, which often erupted into open warfare. It was inevitable that the ups and downs of the Aceh-Dutch and VOC political relations greatly affected trade relations in the West Coast of Sumatra (M.D. Mansoer, 1970: 83-88).

Then with the increasing power of Aceh in the West Coast of the Minangkabau that began in the mid-16th century, after the fall of Malacca to the Portuguese in 1511. Since then, more and more important port cities have emerged on the West Sumatra Minangkabau Coastal Coast, namely Pariaman, Tiku, Padang, Bandar Sepuluh (Painan, Salido, and Batangkapas) and Inderapura (MD Mansoer, 1970: 77-78).

In the 7th century until the 12th century was the first period of the peaceful entry of the Islamic religion into West Sumatra which was introduced by Islamic traders on the Minangkabau coast through the port cities of Pariaman and Tiku. Even though at that time the influence of Islam was limited to the area or city where trade was carried out on the west coast of Sumatra. In the following centuries it continued to the north through the east coast of Sumatra (Irman Gusman, 2012: iv-v).

In the end of the 13th century was the second period of the arrival of Islam into the Minangkabau brought from Aceh. As at that time the west coast areas of Sumatra Island were the territory of the Kingdom of Aceh which previously had also adopted the religion of Islam. There was a process of Islamic traders, while trading also spread the religion of Islam to each of its customers. The coastal areas include Tiku, Pariaman, Air Bangis, and others. Then after the new religion of Islam entered the interior areas of the Minangkabau. Bandar Tiku and Pariaman become an important route for pepper and gold, especially those produced from the highlands and coastal areas of Minangkabau. This area is supported by a road that crosses Bukit Barisan which connects the two cities, namely Tiku and Pariaman with the hinterland. Until the end of the 17th century when the Dutch (Kompeni) made Padang its post-trade in the west coast of Sumatra, Pariaman became the largest port city in the region. This trading port city was used as the placement area for the Governor of Aceh and his military, to the north of Pariaman. The term for high ranking Acehnese officials is commonly called 'teuku' so that based on the name 'teuku' it is also named after the port location to the north of Pariaman as Tiku port or the caliph port (Amir Sjarifoedin Tj.A, 2011: 330).

As the oldest and prosperous port city, Bandar Pariaman has a large trading activity as well. The population was large after the mid 16th century, after the arrival of traders and religious teachers from Aceh to the region. The arrival of merchants, scholars, and religious teachers also had significance for the historical development of Tiku and Pariaman in the following centuries (M.D. Mansoer, 1970: 77).

Furthermore Sultan Alauddin Riayatsjah al-Qahhar had appointed one of his sons as commander of the syahbandar in Pariaman. His activities are very persistent in developing Islamic religion and opening pesantren in Ulakan, and is well-known as Syeh Burhanuddin I, Tuanku Ulakan. During his life up to now Syeh Burhanuddin I has always been respected by the Minangkabau people. Aside from being a prominent figure in the development of the Islamic religion, Syeh Burhanuddin I had also Islamize Supreme Head of Minangkabau, namely Sultan Mohammad Alif (1511). Syeh Burhanuddin I is a great figure who erased the era of "jahiliah" in Minangkabau. Not surprisingly, until now the tomb of Syeh Burhanuddin I was filled with locals for "basapa", that is, the religious ceremony of the month of Syafar (M.D. Mansoer, 1970: 77).

Beginning in the mid-16th century, the Pesisir special area fell under Aceh's political-economic domination. As a result of political-economic domination, the religion of Islam began to develop widely on the Coast (M.D. Mansoer, 1970: 79). For about a century Aceh's political economic dominance on the coast was a special area in ports as a center for trade and religion, such as Tiku, Pariaman, Ulakan, Koto Tangah, Padang, and Inderapura. So there are kinship ties between Aceh's ulama rulers and local residents. This was an obstacle for the Dutch (Kompeni) to implant their political-economic influence on the coast since the mid-17th century (M.D. Mansoer, 1970: 82).

Minangkabau culture is enriched by political and economic ties with Aceh. Arabic languages and letters, the main media for the development of religion and Islamic law, are widespread in Minangkabau. The Arabic script 
which has been simplified from "Malay writing" becomes a tool for writing old literature. This signifies as the cultural heir of Samudra-Pasai and the Kingdom of Malacca. Many of Aceh's cultural heritage in the form of ancient literary works in addition to works of Aceh's creation spread to the Minangkabau Coast. Marked for example by imitating Aceh's magnifying attire and becoming a Minangkabau traditional costume in the Coastal area.Then the "galembong" pants or Aceh pants and Aceh "destar" become Peghulu costume in the Coastal area. Likewise the art of Acehnese construction influenced the form of "Rumah Gadang". The Acehnese words enriched the regional language treasury of the Minangkabau Coast. Other forms are also influenced by Aceh, such as selfdefense tactics through silat which also develop and are widespread in the Minangkabau Coastal area. Including the ability to use weapons in defending the nagari is also studied and inherited from Aceh (M.D. Mansoer, 1970: 82-83).

Thus, in the past, under the rule of the Dutch East Indies colonialist government, the port city of Pariaman was made a trade center on the west coast of the island of Sumatra. Even though gradually the role of this port has been replaced by the Muara port and the Teluk Bayur port located in the city of Padang. But the social, political, economic and cultural life of the city of Pariaman city has been intervened by immigrant rulers such as traders and west colonialist for quite a long time. Not surprisingly, there are various forms of multicultural culture in this region. Evidenced by the emergence of multicultural performing arts forms that developed such as gambus music, gamat and katumbak as a form of Bandar art in Pariaman Coastal West Sumatra.

\section{Deconstruction of Bandar Art}

a. Explore Gambus Music

Based on the conclusions of the Alfathul Mukarram hypothesis explaining that the Persians and Arabs had been trading in the Malay islands in the early 9th century and this instrument was brought to their ships for personal entertainment on the way from Barbad, Qanbus and UD similar to gambus. Allegedly gambus has been introduced by traders when trading along the Malay Archipelago. Then since the opening of the Suez Canal there was a migration of Arabs and Egyptians into the Dutch East Indies in 1870 until after 1888, they brought musical instruments and played Gambus music (2017: 10-11).

Imran in his writings stated that the development of gambus music in Indonesia had begun since the 19th century along with the arrival of Arab immigrants from Hadramaut, South Yemen to Nusantara. As originally gambus music was a means of preaching immigrants, over time, gambus music developed into a means of entertainment. No wonder in the 1940s to 1960s before the emergence of Malay music or better known as dangdut music, gambus music was a dish that was almost never left behind in weddings and circumcision parties (2019: $68)$.

The development of gambus music in Indonesia gave rise to various groups of gambus orchestras in several regions such as Sumatra and Java (Arifin, Zainal. 2012: 68). In 1964, in North Sumatra stood a quite popular gambus orchestra, the Gambus Nur El-Surayya Orchestra. The songs in the Gambus Nur El-Surayya Orchestra are nuanced by the rhythm of the Desert. Gambus orchestra in the cultivation of its music combined Arabic music and Malay nuances in the form of grenek or twisted in singing. "Musical instruments used in gambus music are U'd, violin, accordion, acoustic bass, acoustic guitar, marawis, and flute." (Muhammad Takari and Heristina Dewi, 2008: 115).

In 1970, the Gambus Nur El-Surayya Orchestra held a concert to celebrate the Cultural Week in Padang Pariaman District, West Sumatra. The Gambus Nur El-Surayya performance at that time was well received by the people of Padang Pariaman. This is not only because of his appearance but also because the Gambus Orchestra Nur El-Surayya is a popular Gambus Orchestra in Indonesia (Buya Fuadi Jalil, interview, 5 November 2018, in Pariaman). Long before Nur El-Surayya's arrival in Pariaman, in 1964 in Padang Pariaman District, several wellknown gambus music groups were established, namely: Al-Falah was in Kampung Pauah Padang Pariaman District, Al-Ihsan was in Kampong Pauah Kamba District Padang Pariaman, Nurul Hidayah who are in Kurai Taji Pariaman Selatan, and Al-Hidayah are in Kampung Pondok Kota Pariaman (1995-present). (Lina Marni, interview on November 3, 2018, in Pariaman). Lina Marni further said that, the reason for choosing gambus music in the 1964 era was that she and her friends were inspired by one of the gambus music singers in Egypt, Ummi Kaltsum, known for her extraordinary vocal abilities and style. 


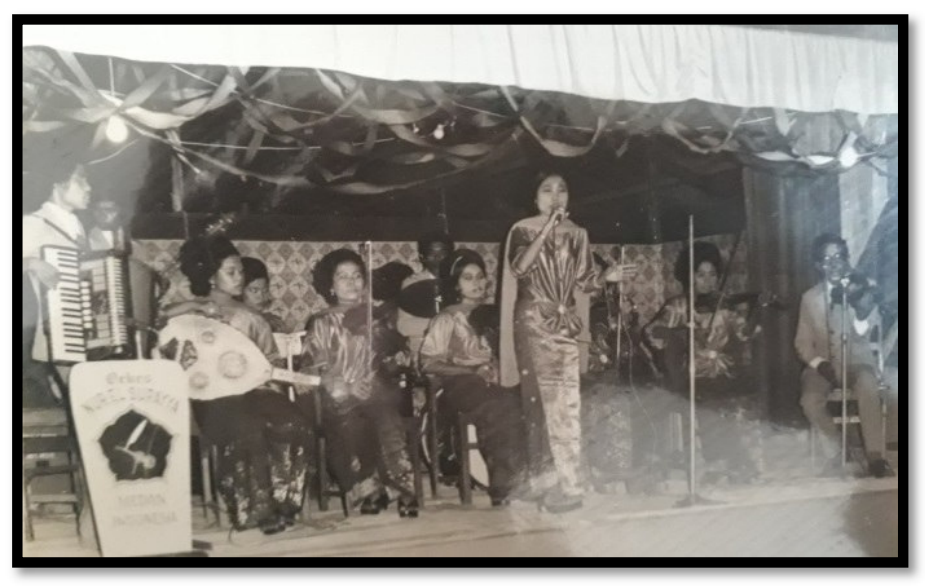

Figure 1. 12-year-old Lina Marni as a young artist vocalist Gambus El Surayya Medan Performing Show in

Payakumbuh 1973 (Photo Document: Martarosa in repero from the documentation of Ms. Lina Marni).

\section{a.1. Gambus Al-Falah Orkes profiles (1964)}

Gambus Al-Falah Orchestra is one of the gambus music groups in Padang Pariaman Regency. According to Lina Marni, the Gambus Al-Falah Orchestra was formed in the 1964s. The Gambus Al-Falah Orchestra Group was founded by Mr. Mansur. The term or name of Al-Falah itself is taken from the fragment of "Azan" (the call to prayer in Islam), which means victory (Lina Marni, interview on November 3, 2018, in Pariaman).

There are several instruments used by the Gambus Al-Falah Orchestra, namely U'd, bass betot (counter bass), flute, violin, and maracas. Gambus Al-Falah Orchestra, almost all of the songs that are presented are sourced from Gambus Nur El-Surayya songs. But the Gambus Al-Falah Orchestra couldn't appreciate Nur El-Surayya's album too much, because in the 1964s it was very difficult to get the albums. From the information of Lina Marni, to get the records of the Gambus Nur El-Surayya Orchestra album, a person had to spend quite a lot of money and wait a few weeks to buy a record. Therefore, as a reference aside from LPs, there used to be another way to appreciate the song Nur El-Surayya through radio broadcasts playing Nur El-Surayya songs on RRI (Radio Republik Indonesia) (Lina Marni, interview November 3, 2018, in Pariaman).

The songs that are often played in every appearance of the Gambus Al-Falah Orchestra are the Desert Rhythm songs such as Selimut Putih, Madah Terakhir, Pusara Kasih, Pemuda Islam and others (Lina Marni, interview on November 3, 2018, in Pariaman). The identical Desert Rhythm songs use traditional Middle Eastern scales on a diatonic and microtonic scale. The song poems also contain praise for the majesty of Allah SWT, the greatness of the Prophet, and the invitation to charity sholeh. Like Selimut Putih song in his poetry that contains moral messages and always remember death.

Lina Marni revealed that in 1964, she was 13 years old at the time, and became the youngest singer in the Gambus Al-Falah Orchestra group. The Gambus Al-Falah Orchestra group was in great demand by the people of Padang Pariaman Regency and outside the district. The popularity of the Gambus Al-Falah Orchestra was demonstrated by frequent guest appearances at various celebrations, thanksgiving, farewell party at the Religious Teacher Education (PGA) school, weddings, events of the 17th of August, and other important events. Gambus Al-Falah Orchestra performance always received good responses from the audience and the community who appreciated this music group. (Lina Marni, interview 12 December 2018 in Kampung Pondok Kota Pariaman).

The style of appearance of the Gambus Al-Falah Orchestra, at that time was still bound by the ethics taught by Buya Hasan Basri. Lina Marni felt that when singing a desert song, with a monotonous expression, she could not interpret the repertoire presented through expressions of gestures, which should be able to describe the meaning of the song poetry being sung. Therefore, Lina Marni considered that the style of appearance at that time was still tacky. (Lina Marni, interview 12 December 2018 in Kampung Pondok Kota Pariaman). The following is a photo of the Gambus Al-Falah Orchestra performance.. 


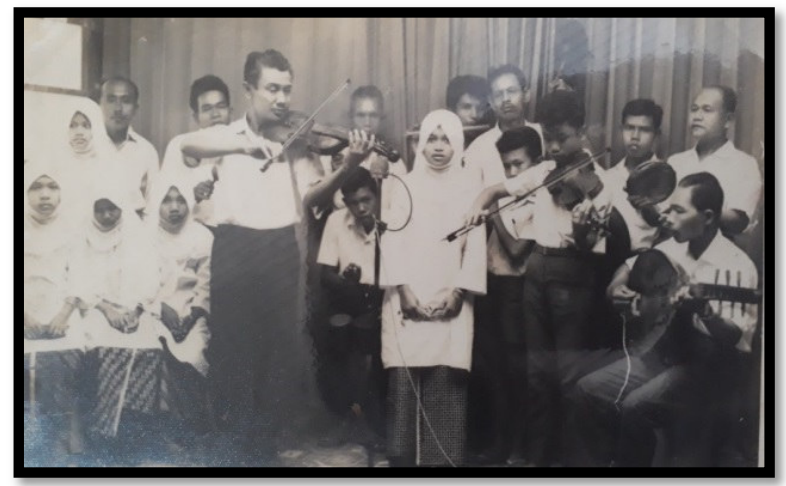

Figure 2. Gambus Al-Falah Orchestra performance in Padangpanjang in the context of The Farewll of Diniyyah Putri students in 1965. (Source: Repro from Lina Marni's documentation).

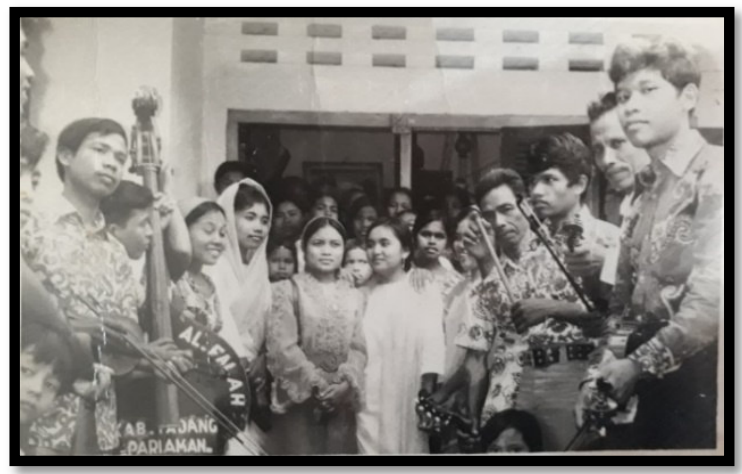

Figure 3. Ibu Lina Marni as vocalist of the gambus orchestra Al Falah at RRI Padang in 1973 (Photo document: Martarosa in repero from the documentation of Ms. Lina Marni).

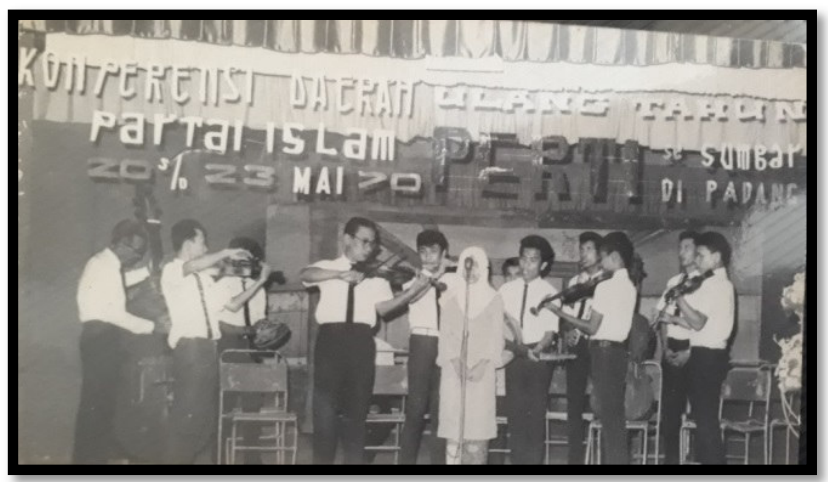

Figure 4. Ibu Lina Marni as vocalist for the Orkes Gambus Al Ikhsan at Imam Bonjol Field in Padang in 1970

(Photo document: Martarosa repero from the documentation of Ms. Lina Marni).

\section{a.2. Profile of Gambus Al-Hidayah Orchestra (1995 to present)}

Al-Hidayah is a music group founded by Lina Marni in 1995. The establishment of the Gambus Al-Hidayah Orchestra is an initiative of Lina Marni and Nurhidayat. They pioneered the Gambus Orchestra that they formed, capitalizing on the desires and experiences of Lina Marni and Nurhidayat during gambus music, as expressed by Lina Marni, "of course we already have enough capital to pioneer the Gambus Al-Hidayah Orchestra group" (Lina Marni, interview on November 3, 2018, in Pariaman).

Since its inception the Gambus Al-Hidayah Orchestra in 1995 began its career performing at events such as weddings, events commemorating Eid al-Fitr, Eid al-Adha, and others. In 2000 the performance of the Gambus Al-Hidayah Orchestra used keyboard instruments, replacing the old musical elements such as the bass band, maracas, and tambourine that existed at the Gambus Orchestra in Pariaman in the 1960s. According to Lina Marni, the presence of a keyboard instrument certainly has a positive impact on economic value, because it is more practical in presenting gambus music (Lina Marni, interview, 5 February 2019, in Pariaman).

As long as the Gambus Al-hidayah Orchestra carries the rhythm of desert songs, it has received positive responses and public enthusiasm for the gambus music presented in the Gambus Orchestra, in terms of 
performances, there are religious values presented through the show, such as clothing or music ( Lina Marni, interview, 5 February 2019, in Pariaman).

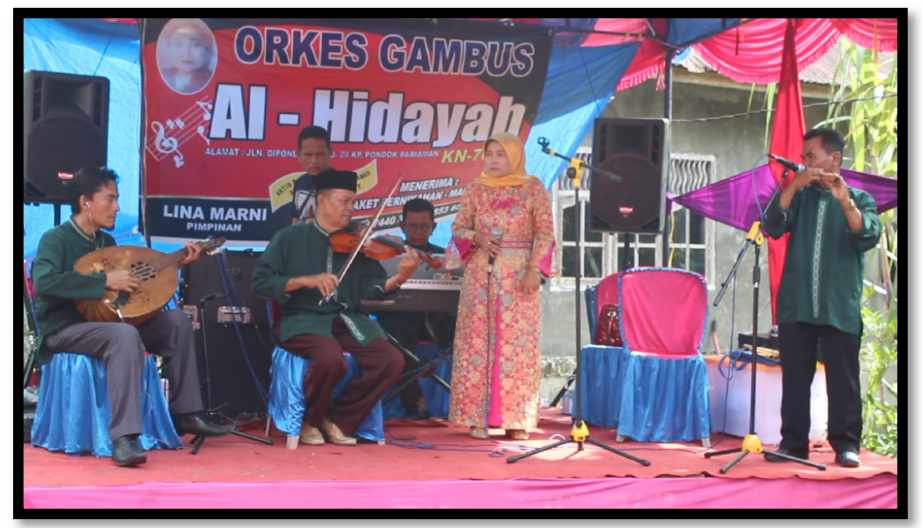

Figure 5. Ms. Lina Marni as a singer artist Gambus Al Hidayah in Pariaman City in 2019 (Photo Document: Martarosa in repero from the documentation of Ms. Lina Marni).

\section{a.3. Instrumentation of the Gambus Al-Hidayah Orchestra group}

Al-Hidayah Orchestra uses instruments such as violins, keyboards, U'd, and flutes. Each of these instruments has its own role, namely:

a. Violin

The violin is a musical instrument used during the Gambus Al-Hidayah Orchestra performance, this instrument is the same as a conventional conventional violin instrument, the function of this instrument as a filler and melody in performing desert songs.

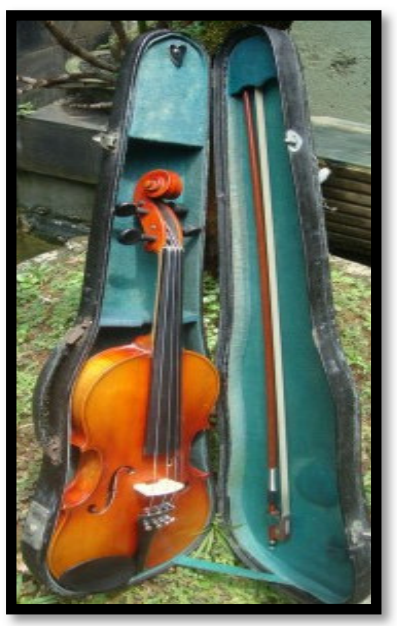

Figure 6. Violin instrument

b. Keyboard

(Photo: Imran Abdoel Gani January 19, 2019 Sungai Limau Pariaman)

The keyboard is a manufacturer's musical instrument that has a variety of tempo, rhythm and genre of music contained in one keyboard application. The keyboard in the Gambus Al-Hidayah Orchestra acts as a filler of harmony and sound of musical instruments. The keyboard plays the role of a void in gambus music. Keyboard musical instruments can accompany a variety of music genres, one of which is gambus music.

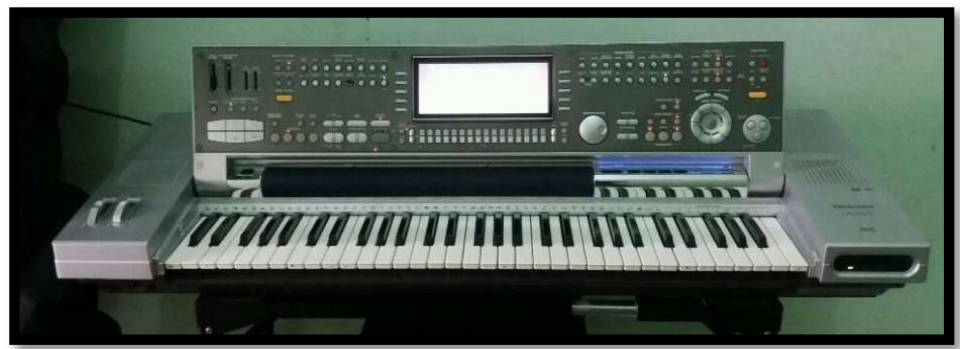

Figure 7. Keyboard instruments (Photo: Imran Abdoel Gani 19 January 2019). 
c. U'd

The musical instrument U'd is a musical instrument which is organologically the same as U'd in Arabic. The U'd instruments arrived on the island of Sumatra brought by Arab, Gujarat and Persian immigrants who came to trade. Geographically Pariaman is located in a coastal area, which allows easy access for Arab, Gujarat and Persian immigrants to bring the U'd musical instrument to the area.

U'd consists of 10 strings. According to Desri's statement, U'd instrument is a characteristic of the Gambus Al-Hidayah Orchestra music, because the sound produced by U'd makes the nuances of desert rhythmic music sound very thick. U'd function in the Gambus Al-Hidayah Orchestra performance as a melody carrier and filler.

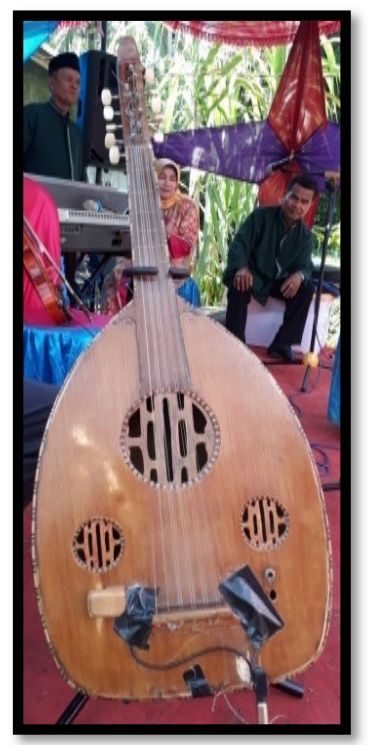

Figure 8. U'd musical instrument (Photo: Imran Abdoel Gani 19 January 2019).

d. Flute (Seruling)

The flute is a wind instrument made of bamboo. The organological shape is thirty $\mathrm{cm}$ long with six holes with a barrel (do-mi-fa-la-si-do). The flute in the Gambus Al-Hidayah Orchestra plays a role as the main melody carrier and filler in accompanying gambus music.

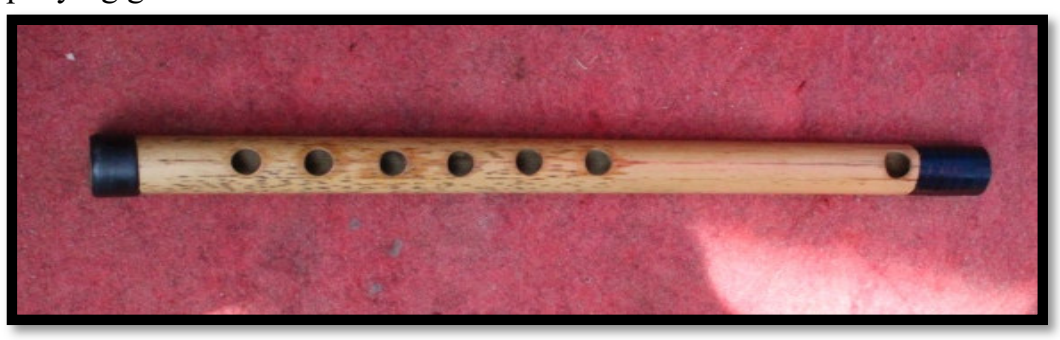

Figure 9. Flute music instrument

(Photo: Imran Abdoel Gani 19 January 2019)..

\section{b. Gamat Music}

It is not easy to trace the existence of gamat music present in the port community in Pariaman. There have not been found articles or journals about the growth and development of gamat music in the city community, although efforts to find the necessary data are still being made. According to Nasrun Jon, a figure and gamat music singer in the City of Pariaman, people used to play gamat music while they were waiting for the tides, they were playing music, singing and doing rhymes. The poem tells about hardship, luck, or affection. At that time the story 'unrequited love' was very popular to tell.

The popularity of gamat music in Pariaman is also contained in gamat song poetry as written, "Piaman ..., tadanga langang batabuik magkonyo rami ....". The meaning of the fragment of the lyrics is that on ordinary days Pariaman is always quiet and only gets busy when a tabuik party is held. Furthermore, the existence of the gamat music group in Pariaman can be traced through the title of the gamat song, which is Dayuang Piaman. The emergence of the gamat song titled Dayuang Piaman is originated from the story of Pariaman children rowing with a canoe in the sea. That story is sung the same as the title song Gamat Dayuang Palinggam. Most of the naming for a song title is based on where it is located and what happened, because generally those who play gamat music 
are people who are in the beach area.

Formation of musical instruments presented consisted of 2 violins, 1 alto saxaphone, 1 organ, 1 drum, and 1 maracas, 1 tambourine, and vocal.

The repertoire of songs presented included Kaparinyo, Dayuang Piaman, Siti Payung, Sitikam, Mati Dibunuah, Sarunani Aceh, Simambang Gunuang, and Buruang Putiah. Then the types of Malay songs such as Sri Mersing, Anak Tiung, Anak Kala, Lanser, Bunga Tanjung, and Tanjung Katung. The procedure for playing gamat music starts with an opening greeting by singing the song Kaparinyo, then for the closing song is Duo. In the Kaparinyo song the singers involved were treated to a shawl / handkerchief to dance in pairs in the form of a dancing rhythm, consisting of two to four people. Nowadays gamat music in Kota Pariaman is hard to find and is considered rare.

Previously apart from the gamat music group, there were several active music groups that were used for wedding parties in Pariaman, such as gambus music groups, batumbak music groups, gandang tambua music groups, band groups, simarantang / randai arts groups, and indang music groups. (Interview with Mr. Nasrul Jon, observer of gamat music and also as gamat singer in Kota Pariaman).

Nasrul Jon further said that the presence of gamat music in the City of Pariaman has existed since the 1950s. The formation of musical instruments played consisted of violins, accordions, drums, maracas, tambourine, and vocals. At that time in the city of Pariaman music gamat was used for weddings and Oyak Tabuik (Goyang Tabot) events which were held once a year. However, until the 1990s these two forms of music were displaced due to the emergence of single organ music which in its appearance was low cost and had few players. At present, the gamat music group in Kota Pariaman has only one group left with incomplete players. This gamat music group is called the group "Orchestra" (Interview with Mr. Norman, aside from being a teacher, he is also a gamat music player in Kota Pariaman) (Interview with Nasrul Jon, music observer of gamat and gamat singer of Kota Pariaman).

"Gamat Melayu Dayuang Pariaman", the players were imported from the cities of Padang and Padangpanjang. Many of the gamat musical performances were only carried out in the context of batabuik (playing tabot) and New Year celebrations. However, at this time gamat music performances in a wedding party in Pariaman it is rarely found as is often found in the cities of Padang and Pesisirselatan.

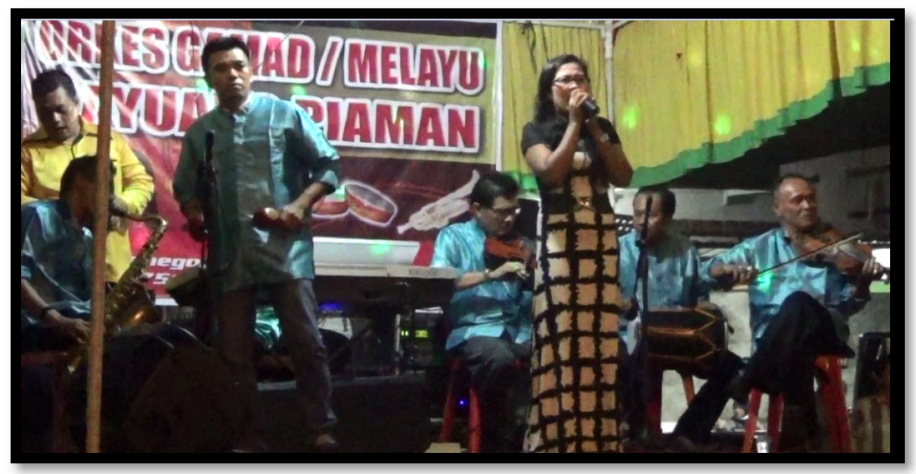

Figure 10. Gamat / Malay Dayuang Piaman Orchestra Group (Documentation: Martarosa, Kota Pariaman, 29 September 2015)

\section{c. Katumbak Music}

Katumbak music is a small ensemble that grows and develops in Padang Pariaman Regency. Instrument formation used consisted of 1 rabunian pupuik (harmonium), 1 double-faced drum or also called "gendang ketipung" 24, 1 mambo drum, 1 tambourine, and vocal. The arrival of the Cipahi Indians is thought to have spearheaded the emergence of katumbak music which grew and then developed in various areas of Padang Pariaman Regency to date, including: (1) Kampuang Toboh, Lubuk Alung District; (2) Basuang Village, Ampalu Village District V Koto Kampung Dalam; (3) Nagari Limau Puruik District V Koto Timur; and (4) Labuang Dalam North Pariaman District. Continued in the 1970s and 1980s this katumbak music had reached the peak of its glory as entertainment in a variety of community events, such as weddings, bridal processions, and alek nagari (people's parties). The various repertoires that are presented in the Gendang Ketipung music in two-faced form or in Pariaman are called the katumbak drum, resembling the drum used in gamat performances. Katumbak adapted gamat, dangdut, and several Indian songs. Some gamat songs specifically adapted by katumbak music players are Kaparinyo, Siti Payung, Saruanai Aceh, Mati Dibunuah, Siti Padang, Kapa Perak, Bungo Tanjuang, Budi Nan Baiak, Lagu Duo, and many others (Yurnalis, 2012: 265 -266)

One of the existing katumbak music groups is the "Katumbak Bujan" music group. This group is creative in innovating musical instruments that are presented, such as drums and mambo, no longer using cow or goat leather, but have been replaced with glass fiber, as well as harmonium musical instruments are also updated. Even though the formation of katumbak musical instruments is currently developing, coupled with electric bass and organs, for 
the procession of the procession the bride and groom still use the musical instrument formation as before. Performances and musical instruments used by the musical group "Katumbak Bujan" can be seen in the following picture.

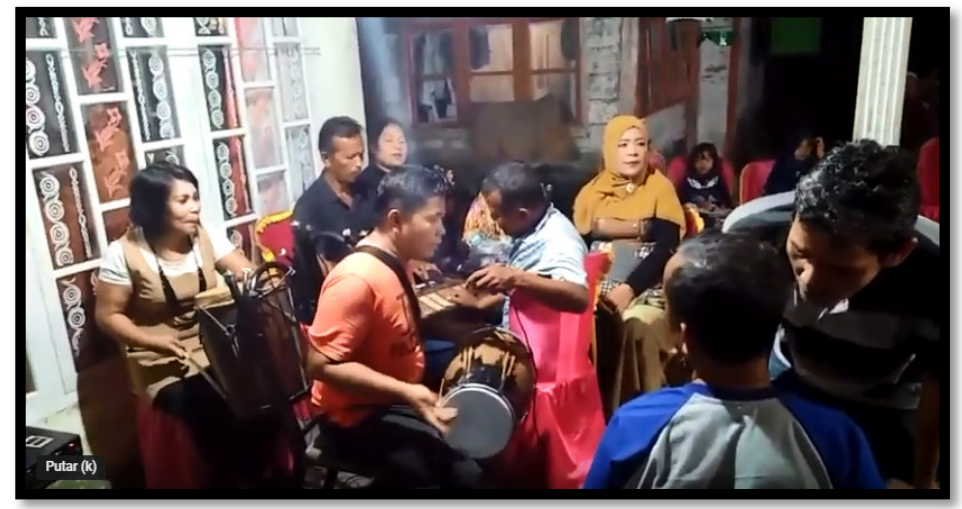

Figure 11. Katumbak music group (Document: Martarosa ransomed from the old Minang music video https:/www.youtube.com/watch?v=JKVqE2Ky0q4, accessed on September 8, 2019

\section{CONCLUSION}

It can be concluded that in the past under the rule of the Dutch East Indies colonialist government the port city of Pariaman was used as a trading center on the west coast of the Sumatra islands. Although the role of this port has gradually declined and was replaced by the port of Muara and Teluk Bayur in the city of Padang. However, the interests of the authorities in the social, political, economic and cultural areas of the port city of Pariaman were intervened by many migrants such as traders and western colonialists for a long period of time. It is not surprising that multicultural diverse cultural forms occur in this region. Evidenced by the emergence of multicultural performing arts forms that develop such as gambus music, gamat and katumbak as a form of port art in Pariaman Coastal West Sumatra.

The growth and development of gambus music in Nusantara was begun in the 19th century. It is suspected that gambus music developed in Pariaman as a port city of the Minangkabau coast consists of three classifications including: (1) Arabic style traditional gambus music with the characteristics of singing Arabic text and using instruments music consists of one gambus instrument called also U'd and several tambourines and a number of drums added; (2) classical style gambus music with the characteristics of singing Indonesian-language song texts besides using gambus as the main instrument is also added by using Western musical instruments such as: a group of violins, guitars, harmonium, contra bass pluck, string cello, tambourine, flute and maracas, and ; (3) modern style gambus music characterized by singing Indonesian song texts using musical instruments consisting of gambus, accordion, violin, organ / keyboard and flute. Thus it can be said that the development of gambus music in this area has been a long time, it can be used as a prototype for the development of other similar music groups such as gamat and katumbak music. Besides the use of instrument formations which are equally influenced by the West, the form and structure of the songs sung also share such as: intro, main song, interlude and coda.

\section{References}

Amir Sjarifoedin Tj.A (2011), Minangkabau dari Dinasti Iskandar Zulkarnain Sampai Tuanku Imam Bonjol, Jakarta: PT Gria Media Prima.

Anthony Reid (2011), Asia Tenggara dalam Kurun Niaga 1450-1680 Jilid 2: Jaringan Perdagangan Global (Terjemahan: R.Z. Leirissa dan P. Soemitro, Jakarta: Yayasan Pustaka Obor Indonesia.

Arifin, Zainal (2012). "Fungsi Gambus dalam Musik Melayu Deli di Sumatera Utara", Grenek Musik Journal,. Universitas Medan, 1 (1).

Derrida, Jacques (1994), Of Grammatology (trj) Gayatri Spivak, Washington DC:Johns Hopkins University Press. Gusti Asnan (2007), Dunia Maritim Pantai Sumatera, Jogjakarta: Ombak.

Imran Abduk Gani, Wilma sriulan, Asril (2019), "Dekulturasi Bentuk Seni Pertunjkan Orkes Gambus di Kota Pariaman Provinsi Sumatera Barat, JURNAL SENI MUSIK, 8 (1), 67-73.

Irman Gusman (2012), "Sambutan Ketua DPD RI", dalam H, Walneg S. Jas, Windo Wibowo, Padang di Persimpangan Jalan? Potretnya Dahulu, Kini, dan Visi Masa Depan”, Jakarta: PT Visi Media Nusantara.

Martarosa, GR. Lono Simatupang, Timbul Haryono, Victor Ganap (2016), “Apropriasi Musikal dan Estetika Musik Gamat”, RESITAL, 17 (1), 19-29.

-------, Imal Yakin, Kurniawan Fernando (2019), “Kesenian Ronggeng Pasaman Dalam Perspektif Kreativitas Apropriasi Musikal”, MUDRA, 34 (1), 87-96. 
M.D. Mansoer, Amrin Imran, Mardanas Safwan, Asmandar Z. Idris, Sidi I. Buchari (1970), Sedjarah Minangkabau, Djakarta: Bharatara.

Mohd. Ramli Raman (1996), "Kaedah Penulisan Laporan Penyelidikan" dalam Adat Istiadat Melayu Melaka", Institut Kajian Sejarah dan Patriosme Malaysia dengan Kerjasama Kerajaan Negeri Melaka, Kuala Lumpur: Akademi Pengajian Melayu, Universitas Malaya.

Mukarram, Alfathul (2017), "Identitas Budaya Musik Gambus Di Palembang”, dalam Imaji, Jurnal Seni dan Pendidikan Seni, 15 (1), 9-23.

Simatupang, Lono (2013), Pergelaran Sebuah Mozaik Penelitian Seni-Budaya, Yogyakarta: Jalasutra.

Suwardi M.S. (2008), Dari Melayu ke Indonesia: Peranan Kebudayaan Melayu dalam Memperkokoh Identitas dan Jati Diri Bangsa, Yogyakarta: Pustaka Pelajar.

Takari, Muhammad dan Heristina Dewi (2008), Budaya Musik dan Tari Melayu, Medan: USU Press.

W.F. Wertheim (1999), Masyarakat Indonesia dalam Transisi Studi Perubahan Sosial (Terjemahan: Misbah Zulfa Ellizabet), Yogyakarta: PT Tiara Wacana Yogya.

Yurnalis (2012), “Orkestrasi Musik Sinkretik Katumbak di Nagari Limau-Puruik Pariaman”, EKSPRESI SENI, $14(2), 1-14$

Zainal Kling (1996), “Adat” dalam Adat Istiadat Melayu Melaka, Institut Kajian Sejarah dan Patriosme Malaysia dengan Kerjasama Kerajaan Negeri Malaka, Kuala Lumpur: Akademi Pengajian Melayu, Universitas Malaya.

\section{Webtografi:}

Video musik Katumbak Minang lama https://www.youtube.com/watch?v=JKVqE2Ky0q4, diakses pada Tanggal 8 September 2019. 